\title{
Ile Europy w europejskich mediach informacyjnych? Rola mediów w ksztaltowaniu europejskiej sfery publicznej
}

\section{Wprowadzenie}

Jednym z wyzwań związanych z integracją europejską jest zjawisko „deficytu komunikacyjnego", czy też „luki komunikacyjnej” występującej w relacji pomiędzy instytucjami UE a obywatelami państw członkowskich. Efektem tej luki jest nie tylko stosunkowo niewielka wiedza o funkcjonowaniu poszczególnych instytucji i o płaszczyznach integracji, ale też niski stopień poczucia tożsamości europejskiej (Meyer, 1999; Schlesinger, 1999; Perez, 2013). Problem ten został dostrzeżony stosunkowo późno: rozważania nad europejską sferą publiczną i rolą mediów w procesie jej kształtowania rozpoczęły się $\mathrm{w}$ gruncie rzeczy dopiero w połowie lat 90. (Eriksen, Fossum, 2000; Habermas, 1998, 2000; Schlesinger, Kevin, 2000). Od tego czasu europejska sfera publiczna jest postrzegana jako swoista przestrzeń, w której odbywa się debata publiczna dotycząca kierunków działań i poszczególnych decyzji podejmowanych w ramach instytucji unijnych i tym samym jeden $\mathrm{z}$ kluczowych elementów wzmacniających integrację europejską.

U podstaw koncepcji europejskiej sfery publicznej leży przekonanie, że przepływ informacji oraz możliwość debaty sprzyjać będzie wzmacnianiu demokracji oraz budowaniu tożsamości europejskiej wśród narodów państw członkowskich (Offerhaus, Mollen, Hepp, 2014, s. 15). Zjawisko europeizacji sfery publicznej analizowane jest w kontekście kształtowania kolektywnej tożsamości europejskiej („My - Europejczycy”) i budowania międzynarodowej społeczności, czy też międzynarodowej opinii publicznej. Badania nad realizacją tej koncepcji ukazały, że europejskiej sfery publicznej nie można - jak pisał J. Gripsrud (2007) - stworzyć poprzez rozbudowanie lub „zeuropeizowanie" narodowych sfer publicznych - jest to bowiem zjawisko znacznie bardziej złożone.

W literaturze przedmiotu wyróżnia się dwa podstawowe wymiary europeizacji sfery publicznej: wertykalną i horyzontalną (Koopmans, Erbe, 2004; Wessler et al., 2008; Koopmans, Statham, 2010; Hepp et al., 2012). Wymiar wertykalny odnosi się do monitorowania działań podejmowanych przez instytucje unijne w poszczególnych państwach członkowskich (czyli m.in. do opisywania ich przez media narodowe i dyskutowania o nich w ramach narodowych sfer publicznych), natomiast horyzontalny do relacjonowania wydarzeń i spraw dotyczących innych państw europejskich. W każdym z tych wymiarów wyodrębnić można jeszcze dodatkowo aspekt oddziaływania i aspekt dys- 
kursu narodowego. W efekcie otrzymujemy czterowymiarowy model europeizacji sfery publicznej (Peters, 2008, s. 200; Offerhaus, Mollen, Hepp, 2014, s. 15), obejmujący wertykalny wymiar relacjonowania działań instytucji UE; wertykalne kształtowanie europejskiej tożsamości zbiorowej, horyzontalny wymiar wymiany poglądów (wprowadzanie i rozpropagowanie dyskursu paneuropejskiego) oraz horyzontalną konwergencję dyskursu zachodzącą na poziomie narodowych sfer publicznych (upodabnianie się poglądów, ocen, wartości).

Świadomość istnienia deficytu komunikacyjnego w procesie integracji europejskiej zaowocowała szeregiem inicjatyw podejmowanych przez instytucje unijne i państwowe. Wykorzystywane są w nich zarówno narzędzia komunikacji bezpośredniej, jak i media, w tym media społecznościowe. Niemniej, tradycyjne media, takie jak prasa i telewizja wciąż stanowią jedno z najważniejszych źródeł o bieżących wydarzeniach. Stąd też zarówno w badaniach nad kształtowaniem europejskiej sfery publicznej, jak i podczas planowania praktycznych działań konieczne jest uwzględnienie kryteriów, którymi kierują się media informacyjne podczas selekcji relacjonowanych przez siebie wydarzeń. Celem artykułu jest ukazanie rzeczywistej aktywności mediów w procesie kształtowania europejskiej sfery publicznej, a w szczególności analiza uwagi, jaką media informacyjne poświęcają tematyce europejskiej i unijnej. Przywołane i przeanalizowane zostaną przy tym wyniki badań prowadzonych w ostatnich latach w ramach kilku międzynarodowych projektów badawczych.

\section{„Wartość medialna” Europy i Unii Europejskiej}

Zagadnienie roli mediów w kształtowaniu wiedzy, opinii i postaw wobec integracji europejskiej i Unii Europejskiej prowadzi do jednego z kluczowych obszarów badań nad mediami, tj. problemu efektywności oddziaływania mediów. Zgodnie $\mathrm{z}$ teorią agenda setting, media mogą kształtować przekonanie wśród odbiorców dotyczące tego, które zdarzenia są ważne i którym należy poświęcić uwagę oraz mogą wpływać na to, jakie atrybuty przypisywane są obiektom oraz osobom. Poprzez uwypuklanie określonych cech oraz stosowanie określonego tonu wypowiedzi dziennikarskich, media dostarczają ram interpretacyjnych, czyli pryzmatu, czy też perspektywy, przez którą postrzegane są obiekty i osoby, a także państwa (McCombs, 2006, s. 85-87).

Innymi słowy, obraz państwa w mediach budowany może być poprzez atrybuty poznawcze jemu przypisywane (czyli dodatkowe informacje, tematy, zdarzenia, które powiązane są z danym państwem w materiałach prasowych), jak i atrybuty afektywne (wypowiedzi oceniające, bezpośrednio zaprezentowane nastawienie wobec państwa np. w komentarzach i ocenach formułowanych przez dziennikarzy lub innych autorów). Teoria ta była wykorzystywana m.in. w badaniach nad informacjami zagranicznymi przeprowadzonych przez W. Wantę i S. Mikusovą (2010).

Wpływ na ostateczny kształt przekazu (i potencjał oddziaływania) mają takie czynniki jak: rodzaj medium informacyjnego (wpływ silny, ale krótkotrwały w przypadku telewizji oraz wpływ bardziej długotrwały w przypadku gazet), rodzaj historii (umiejscowienie i sposób prezentacji nadające określony charakter informacji) oraz stopień emfazy, czyli rozłożenie akcentów (poświęcanie większej uwagi danej informacji np. 
poprzez wielokrotne jej powtarzanie). Kluczową rolę odgrywa przy tym proces selekcji wydarzeń i spraw dokonywany przez media (gatekeeping).

Od lat 30. XX wieku prowadzone są badania empiryczne ukazujące, ile uwagi i miejsca poświęca się wydarzeniom mającym miejsce poza granicami danego państwa oraz w jaki sposób dziennikarze starają się przybliżyć te zdarzenia swoim odbiorcom. Wczesne badania (Woodward, 1930; Kayser, 1953) wyraźnie ukazywały znaczenie bliskości geograficznej, społecznej i kulturowej (regionalizm) jako czynnika determinującego proces selekcji informacji zagranicznych. Co więcej, potwierdziły one swoisty „Europocentryzm”, który charakteryzował brytyjska, niemiecką i amerykańską prasę drukowaną już w XVII, XVIII i XIX wieku (Wilke, 1987). Badania z lat 60. XX wieku (Galtung, Ruge, 1965) potwierdziły, że im lepiej odbiorcy są obeznani z danym wydarzeniem ze względu na bliskość kulturowa, bądź spojrzenie etnocentryczne i im większe prawdopodobieństwo, że może mieć ono wpływ na ich własne życie, tym większe prawdopodobieństwo, że stanie się ono wiadomością. Ponadto, wydarzenia, w których uczestniczą znaczące i wpływowe narody, czy też ważne osoby (tzw. elity), mają dużą wartość informacyjną ze względu na zainteresowanie nimi szerokiej publiczności.

Efektem takiej selekcji wydarzeń jest brak równowagi w zakresie prezentacji poszczególnych regionów świata i państw w mediach, na co zwracali uwagę w szczególności badacze prowadzący swoje analizy w latach 70. i 80. XX wieku. Badania G. Gerbnera i G. Marvanyi'a (1977) oraz projekt „Foreign Images” (Sreberny-Mohammadi i inni, 1985) dostarczyły empirycznych danych potwierdzających wcześniejsze spostrzeżenia, że wszędzie na świecie najwięcej uwagi poświęca się temu, co dzieje się w państwach należących do najbliższego regionu geograficznego. Na drugim miejscu pod względem częstotliwości relacjonowania znalazły się wielkie mocarstwa, zaś na trzecim regiony, w których miały miejsce konflikty i kryzysy. Dopiero w dalszej kolejności media poświęcały uwagę mniejszym i mniej istotnym politycznie lub gospodarczo państwom. Późniejsze badania (Chang, Lee, 1992; Sreberny, Stevenson, 1999; Wu 1998, 2000; Harcup, O’Neil, 2001) pozwoliły na sformułowanie nowych list czynników sprzyjających skupieniu uwagi mediów na wydarzeniach zagranicznych (m.in. personalizacja, odniesienie do państw lub jednostek zaliczanych do elit, krótkotrwałość, zaskoczenie, znaczenie) i na każdej z nich znalazła się także bliskość geograficzna i kulturowa (regionalizm).

Znaczenie regionalizmu jako czynnika sprzyjającego zainteresowaniu mediów zagranicznych potwierdziły także niedawne badania prowadzone przez $\mathrm{Ch}$. Heimprecht i J. Wilkego w ramach międzynarodowego projektu „Foreign News on TV” (więcej o projekcie w: Cohen i inni, 2013). Z badań tych wynika, że wśród sześciu europejskich państw uczestniczących w tym projekcie (Belgia, Niemcy, Polska, Portugalia, Szwajcaria i Włochy) ponad połowa informacji zagranicznych (55\%) prezentowanych w wybranych telewizyjnych programach informacyjnych dotyczyła wydarzeń, które miały miejsce w innym państwie europejskim (Wilke, Heimprecht, 2011). Pozostałym regionom świata poświęcano mniej uwagi. Co ciekawe, również w całej próbie (łącznie 17 państw z różnych kontynentów) Europa była najczęściej prezentowanym regionem - jedna trzecia wszystkich informacji zagranicznych dotyczyła państw europejskich. Ameryce Północnej poświęcono 24\%, Bliskiemu Wschodowi 20\%, Azji 19\%, Amery- 
ce Południowej 12\%, zaś Australii i Oceanii oraz Afryce jedynie po 3\% wszystkich informacji zagranicznych.

Jednocześnie media w państwach europejskich były najbardziej skupione na informacjach dotyczących swojego własnego regionu, podczas gdy w Azji informacje o państwach z regionu zajmowały $46 \%$ informacji zagranicznych, w Ameryce Południowej 40\%, na Bliskim Wschodzie 38\%, zaś w Ameryce Północnej 36\%. Warto przy tym wskazać, że wśród państw europejskich objętych badaniem istniały różnice. Najwięcej uwagi państwom europejskim w telewizyjnych programach informacyjnych poświęcano w Polsce (aż 72\%), podczas gdy w Niemczech mniej niż połowa (48\%) materiałów dotyczyła wydarzeń europejskich (Wilke, Heimprecht, Ito, 2013, s. 66-67). W pozostałych państwach informacje o Europie obejmowały od 50 do 58\% wszystkich informacji zagranicznych.

Przejawem regionalizmu jest także uwaga, jaką poświęca się w mediach państwom sąsiedzkim. Spośród 17 państw uczestniczących w projekcie „Foreign News on TV” w 5 najwięcej informacji zagranicznych poświęcono właśnie państwu sąsiadującemu: Argentynie w Chile, Rosji w Polsce, Hiszpanii w Portugalii, Malezji w Singapurze oraz Palestynie w Egipcie. Wśród państw europejskich wysoko na listach najczęściej prezentowanych państw były także inni przedstawiciele regionu - państwa o dużym znaczeniu politycznym, gospodarczym, militarnym: Francja, Wielka Brytania, Niemcy oraz Włochy (Wilke, Heimprecht, Ito, 2013, s. 70-71).

Z kolei wyniki badań nad zawartością prasy lokalnej z kilku europejskich państw (Offerhaus, Mollen, Hepp, 2014, s. 23-26) pokazały, że nieco ponad połowa materiałów dotyczyła tylko i wyłącznie własnego państwa, podczas gdy w 18\% materiałów pojawiały się państwa europejskie. Analizując dane z lat 1982-2008 zauważyć można wzrost odniesień do innych państw europejskich (z 15\% w 1982 roku do $20 \%$ w 2008 roku). Najwięcej takich materiałów opublikowanych było w prasie w Austrii i Polsce (23\%), czyli w tych państwach, które spośród badanych najpóźniej przystapiły do UE, najmniej zaś w najbardziej eurosceptycznych państwach w próbie, tj. w Wielkiej Brytanii (10\%) i Danii (17\%). Natomiast jedynie 5\% spośród osób wypowiadających się w tej prasie reprezentowało inne państwa europejskie (podczas gdy 83\% swoje własne państwo). Z badań tych wynika zatem, że więcej uwagi poświęca się prezentacji państw europejskich niż wymienianiu poglądów i opinii przedstawicieli tych państw.

Unia Europejska jako organizacja międzynarodowa (lub jej instytucje, takie jak Komisja Europejska, Parlament Europejski lub Europejski Bank Centralny) przywoływana była dotąd w relatywnie niewielkiej liczbie informacji. Wyniki badań prowadzonych w państwach europejskich uczestniczących w projekcie „Foreign News on TV" (Wilke, Heimprecht, Ito, 2013, s. 70-71) pokazały, że np., w Belgii 30 informacji telewizyjnych w pierwszym kwartale 2008 roku zawierało bezpośrednie odniesienie do UE (4\% informacji innych niż wyłącznie krajowe), w Niemczech: 40 (8,5\%), w Polsce: 23 (8\%), w Portugalii: 24 (4\%), zaś w Szwajcarii: 45 (5\%).

Nawet w Belgii, której stolica stanowi siedzibę wielu instytucji unijnych, tematyce obejmującej różne aspekty działania Unii Europejskiej nie poświęca się więcej uwagi niż w innych państwach (De Swert, 2009; 2011). W latach 2003-2013 w programach publicznej i komercyjnej telewizji średnio $2 \%$ materiałów poświęcona była tematyce 
unijnej. Oznacza to, że średnio jedna informacja (o średniej długości 48 sekund) emitowana była w TV co drugi dzień. Niemniej, od 2009 roku zaobserwować można zwiększenie zainteresowania mediów belgijskich tematyką unijną. $Z$ badań nad tematyką i sposobem prezentacji (De Swert, De Smedt, 2014) wyraźnie wynika, że przyczyniło się do tego mianowanie Belga - Hermana Van Rompuya pierwszym stałym przewodniczącym Rady Europejskiej (potocznie nazywanym „prezydentem Unii Europejskiej”). W tym przypadku zauważyć można wystapienie kilku czynników sprzyjających zainteresowaniu mediów danym tematem: jednostka (,personalizacja”), pochodząca z danego państwa obejmuje kluczową funkcję (,elita”).

Wskazać można także szereg badań, które dotyczyły relacjonowania w mediach narodowych głównych wydarzeń europejskich takich jak: wybory do Parlamentu Europejskiego, referenda, wprowadzenie wspólnej waluty czy szczyty europejskie (zob. m.in. de Vreese, 2001; de Vreese, Peter, Semetko, 2001; de Vreese, Semetko, 2004; de Vreese, Boomgaarden, 2005; Wilke, Reinemann, 2007; Maier, Strömbäck, Kaid, 2012). Wyniki analiz zawartości prasy prowadzą do wniosku, że media koncentrują swoją uwagę na tematyce europejskiej czy też unijnej cyklicznie: przy okazji wydarzeń, które mają charakter krótkotrwały, bardziej intensywny i przynoszą zmiany, których konsekwencje mogą być odczuwane przez społeczeństwa w poszczególnych państwach.

Badania te dotyczyły głównie zawartości telewizyjnych programów informacyjnych oraz prasy opiniotwórczej o zasięgu ogólnokrajowym (zob. m.in. Trenz, 2004; Veltri, 2012; de Vreese, 2001), podczas gdy zawartość tabloidów czy prasy regionalnej analizowana była znacznie rzadziej. Tymczasem oba typy prasy mają istotny potencjał oddziaływania na opinie i postawy obywateli. W prasie regionalnej tematyka zagraniczna prezentowana jest co prawda stosunkowo rzadko, ale selekcjonowane i opisywane są wydarzenia oraz problemy mające bezpośredni wpływ na mieszkańców danego regionu. Badania nad zawartością wybranych tytułów prasy regionalnej z $\mathrm{Au}-$ strii, Danii, Francji, Niemiec, Polski oraz Wielkiej Brytanii ${ }^{1}$ z lat $1982-2008$ przeprowadził zespół z Uniwersytetu w Bremie. Wyniki badań prowadzonych w ramach projektu „The Transnationalization of Public Spheres in the EU: Citizens' (re)actions” pokazują że choć tematyce polityki unijnej poświęcano jedynie $4 \%$ materiałów, a narodowe instytucje prezentowane są w mediach najczęściej (72\%), to blisko jedna piąta (19\%) prezentowanych w badanej dekadzie w prasie regionalnej instytucji ma charakter instytucji unijnej (Offerhaus, Mollen, Hepp, 2014, s. 9). Co więcej, zauważyć można wzrost częstotliwości występowania tego typu instytucji w analizowanych tytułach prasy regionalnej: z 10\% w 1982 roku do $23 \%$ w 2008 roku. Jednocześnie, w okresie tym malała stopniowo częstotliwość występowania instytucji narodowych (z 78\% do $69 \%$ ). Jednym z powodów tych zmian może być fakt, iż określone kwestie regulowane są przez instytucje unijne (np. dotacje).

Informacje poświęcone UE podlegają w mediach tzw. „ukrajowieniu” (domestication): media stosują taktyki mające na celu podkreślenie związku wydarzenia zagra-

1 Analizie poddano zawartość następujących tytułów prasowych: „Westdeutche Allgemeine Zeitung” (Niemcy), „Ouest France” (France), ,Manchester Evening News” (Wielka Brytania), „Kleine Zeitung” (Austria), „Jydyske Vestkysten” (Dania) oraz „Dziennik Zachodni” (Polska). 
nicznego z krajowymi odbiorcami (podkreślanie udziału osób reprezentujących dane państwo oraz ukazywanie wpływu wydarzeń na odbiorców krajowych). Co ciekawe, dotyczy to także Belgii, choć w tym przypadku informacje o tematyce unijnej nie mają $\mathrm{w}$ istocie charakteru informacji typowo zagranicznych, raczej należą do tzw. informacji hybrydowych: krajowych z elementami zagranicznymi (kategoria ta wyodrębniona jest na podstawie kryterium lokalizacji wydarzenia i wpływu lub udziału przedstawicieli innych państw (Almaney, 1970).

W mediach informacyjnych rzadko przywoływane są natomiast wizje wspólnej europejskiej tożsamości (Offerhaus, Mollen, Hepp, 2014, s. 27-29) - w badaniu zawartości lokalnej prasy drukowanej w 6 państwach europejskich jedynie 5\% materiałów zawierała odwołania do Europejczyków, podczas gdy w jednej czwartej materiałów w całej próbie odnotowano odwołania do wspólnoty narodowej (np. „my Polacy” w przypadku prasy polskiej), zaś w $18 \%$ - do innych europejskich narodowości (Niemcy, Brytyjczycy itd.). Co ciekawe, wciąż obecna jest w prasie regionalnej kategoria zbiorowa „Zachód” - pojawiła się ona w 7\% materiałów, czyli w większej liczbie niż „Europejczycy”. Analizując wyniki długookresowego badania porównawczego widać w tym zakresie istotną zmianę: o ile w roku 1982 kategoria „Zachód” przywoływana była przez dziennikarzy w 11\% materiałów o tyle, w 2008 r. w jedynie 3\% materiałów. Zmianie tej nie towarzyszyło jednak częstsze przywoływanie kategorii „Europejczycy" (7\% w 1982 roku, 3\% w 2008 roku).

\section{Medialne obrazy prezydencji w Radzie UE}

W badaniach nad medialnym obrazem prezydencji w Radzie UE wyróżnić można dwie perspektywy analizy: „krajową” i „europejską”. W pierwszej prezydencja jest postrzegana jako okazja do zbudowania lub zmiany wizerunku państwa na arenie międzynarodowej (europejskiej) poprzez określanie celów i priorytetów oraz ich realizowanie, a także organizowanie wydarzeń (spotkań, imprez kulturalnych) i podejmowanie innych działań mających na celu skoncentrowanie uwagi mediów zagranicznych na danym państwie. Ponadto, prezydencja może stanowić okazję do zbudowania wizerunku państwa wewnątrz (jako państwa członkowskiego, z inicjatywy i na potrzeby polityczne partii sprawujących władzę). W tym przypadku analizie poddawana jest zawartość przekazów prezentowanych zarówno w mediach krajowych, jak i zagranicznych pod kątem występowania materiałów o danym państwie oraz działaniach podejmowanych $\mathrm{w}$ trakcie trwania prezydencji związanych $\mathrm{z}$ tą funkcją bezpośrednio lub też towarzyszących jej pełnieniu.

W drugim ujęciu (,europejskim”) prezydencja postrzegana jest jako okazja do przybliżenia kierunków polityki, regulacji prawnych, instytucji, decyzji oraz działań UE wśród obywateli państwa sprawującego przewodnictwo w Radzie UE (wymiar wertykalny), bądź przybliżenia tematyki unijnej poprzez prezentację państwa sprawującego tę funkcję mieszkańcom innych państw europejskich (wymiar horyzontalny). W tym ujęciu analizowane są wyłącznie materiały dotyczące działań związanych z pełnieniem funkcji przewodnictwa w Radzie UE oraz wszelkie materiały dotyczące problematyki unijnej w ogóle. 
Dotychczasowe badania prowadzone były głównie z perspektywy wertykalnej (Ekengren, 2004; Quaglia, Moxon-Brown, 2006) - sprawowanie przewodnictwa postrzegano głównie jako okazję do przybliżenia własnym obywatelom działań podejmowanych w ramach UE poprzez bieżące relacjonowanie i wyjaśnienie w mediach idei, procedur i decyzji oraz ich znaczenia dla współpracy międzynarodowej oraz dla interesów danego państwa (Boomgaarden i inni, 2010; van Dalen, 2014). Rzadsze były natomiast analizy medialnego relacjonowania prezydencji prowadzone w wymiarze horyzontalnym, czyli badania uwagi, jaką media poświęcają działaniom innych państw podczas ich przewodnictwa w Radzie UE. Badania prowadzone przez C. de Vreese'a (2003; 2005) nad prezydencjami sprzed Traktatu Nicejskiego pokazują, że wówczas faktycznie media koncentrowały się na tematyce unijnej, co wynikało z tego, iż symbolicznie i częściowo także faktycznie Rada Unii Europejskiej przenosiła się do danego państwa - to w nim odbywały się spotkania Rady, tzw. szczyty, którym przewodniczyli przedstawiciele państwa sprawującego prezydencję.

Traktat nicejski wprowadził pierwsze kluczowe zmiany w zakresie przewodnictwa w Radzie UE. Od roku 2003 szczyty unijne nie odbywają się w państwie sprawującym przewodnictwo w Radzie UE, ale w Brukseli. Badania Boomgardena i innych (2010) pokazały, że zmiana ta negatywnie wpłynęła na poziom zainteresowania mediów szczytami europejskimi. Dotyczyło to także mediów w państwach, które w danym momencie sprawowały przewodnictwo. Z kolei Traktat lizboński zmienił dwa najważniejsze traktaty UE: Traktat o Unii Europejskiej i Traktat ustanawiający Wspólnotę Europejską. Wśród zmian wprowadzonych tym traktatem znalazło się rozdzielenie Rady Europejskiej od Rady Unii Europejskiej. Spotkania głów państw (czyli tzw. szczyty) nie stanowiąjuż części programu przewodnictwa w Radzie UE. Ponadto, unijna prezydencja od wejścia w życie Traktatu lizbońskiego ma charakter grupowy (Radzie UE przewodniczą w okresie 18 miesięcy 3 kraje). Co więcej, wzmocniona została rola Parlamentu Europejskiego w unijnym procesie decyzyjnym.

Wszystkie te zmiany istotnie wpłynęł na znaczenie przewodnictwa w Radzie UE (zob. m.in. Husak, 2012; Cianciara, 2012; Mieńkowska-Norkine, 2012) i „oddaliły” prezydencję od państwa, które pełni tę funkcję, co z kolei zmniejszyło zainteresowanie mediów narodowych wydarzeniami towarzyszącymi prezydencji. Ilustrują to wyniki badań przeprowadzonych w Danii przy okazji dwóch prezydencji: w 2002 i 2012 roku (van Dalen, 2014). Podczas tej pierwszej odbył się Szczyt Kopenhaski (12 i 13 grudnia 2002 roku), podczas którego zakończone zostały negocjacje dotyczące rozszerzenia UE. Z kolei w 2012 roku spotkania głowy państw lub szefowie rządów 27 państw spotykali się wyłącznie w Brukseli i w Luksemburgu, a duńska prezydencja stanowiła element trio - z Polską i Cyprem. Z badań A. van Dalena (2014, s. 137-141) wynika, że początek obu prezydencji zainteresował media w podobnym stopniu. W 2002 roku spotkania Rady UE i Szczyt w Kopenhadze ponownie pozwoliły tematyce europejskiej trafić na pierwsze strony duńskiej prasy drukowanej, zaś w 2012 roku takimi wydarzeniami były posiedzenia Parlamentu Europejskiego, choć liczba materiałów im poświęconych była dużo mniejsza niż szczytom w 2002 roku (kilkanaście artykułów w 2012 roku w porównaniu z ponad $40 \mathrm{w} 2002$ roku).

Jednocześnie, utworzono stanowisko Przewodniczącego Rady Europejskiej oraz powołano Wysokiego Przedstawiciela UE ds. Polityki Zagranicznej i Bezpieczeństwa, 
czyli „szefa unijnej dyplomacji”, który przewodniczy Radzie do Spraw Zagranicznych, łącząc wcześniejsze funkcje wysokiego przedstawiciela ds. Wspólnej Polityki Zagranicznej i Bezpieczeństwa oraz komisarza ds. stosunków zewnętrznych) oraz kieruje Europejską Służbą Działań Zewnętrznych. Jedną z konsekwencji tych decyzji jest swoista personalizacja instytucji unijnych, która sprzyja zainteresowaniu mediów państwami, z których wywodzą się jednostki pełniące te funkcje (De Swert, De Smedt, 2014).

\section{Obraz Polskiej prezydencji w prasie polskiej i zagranicznej}

Międzynarodowy projekt „Media Coverage of the Polish EU Presidency”"2 miał na celu sprawdzenie, ile uwagi media w Polsce i za granicą poświęcą pierwszej polskiej prezydencji w Radzie UE oraz w jaki sposób będzie ona prezentowana (więcej o samym projekcie zob. Stępińska, 2013) ${ }^{3}$. Badania w Polsce prowadzone były z perspektywy krajowej (i horyzontalnej): w centrum zainteresowania znajdowała się możliwość kreowania pozytywnego wizerunku Polski na arenie międzynarodowej dzięki zwróceniu uwagi mediów na wydarzenia towarzyszące sprawowaniu tej funkcji. Niemniej, uzyskane wyniki badań pozwalają na sformułowanie bardziej ogólnych wniosków dotyczących zaangażowania mediów w relacjonowanie problematyki unijnej.

Analiza wyników zawartych w tabeli 1 prowadzi do wniosku, że w okresie sprawowania prezydencji jedynie część materiałów dotyczyła tego tematu (od blisko 2\% w prasie drukowanej w Belgii do około 47\% w greckich mediach online). Wyniki badań z Austrii i Niemiec pokazały, że więcej materiałów dotyczących prezydencji publikowanych było w tamtejszej prasie tuż przed objęciem przez Polskę przewodnictwa, niż w okresie sprawowania tej funkcji (Wöhlert, 2013a, 2013b). W pozostałych przypadkach największa uwaga poświęcana była rozpoczęciu prezydencji, później dziennikarze koncentrowali się na tematyce kryzysu gospodarczego w UE. Relatywnie wysoka liczba materiałów w Grecji wynika właśnie z faktu, iż dotyczyły one dyskusji i decyzji dotyczących pomocy dla tego państwa w okresie polskiej prezydencji.

Tabela 1

Informacje o Polsce i polskiej prezydencji w wybranych mediach zagranicznych

\begin{tabular}{||c|l|c|c|c||}
\hline \multicolumn{1}{|c|}{ Państwo } & \multicolumn{1}{|c|}{ Media } & Okres analizy & $\begin{array}{c}\text { Liczba } \\
\text { informacji } \\
\text { o Polsce }\end{array}$ & $\begin{array}{c}\text { \% informacji } \\
\text { poświęconych } \\
\text { polskiej prezy- } \\
\text { dencji }\end{array}$ \\
\hline 1 & \multicolumn{1}{|c|}{2} & 3 & 4 & 5 \\
\hline Austria & $\begin{array}{l}\text { Der Standard } \\
\text { Die Presse } \\
\text { Kronenzeitung Profil }\end{array}$ & $\begin{array}{r}15.06 .-31.07 .2011 \\
1.09 .-15.10 .2011 \\
1.12 .2011-15.01 .2012\end{array}$ & 795 & 7,2 \\
\hline
\end{tabular}

2 Projekt został zrealizowany w latach 2011-2014 ze środków NCN - grant na badania własne (NN116 614440, kierownik: A. Stępińska).

3 Wyniki badań poszczególnych zespołów zawarte zostały w anglojęzycznym numerze specjalnym „Środkowoeuropejskich Studiów Politycznych” nr 3 z 2013 roku. W tym samym czasie inne badania nad zawartością prasy polskiej prowadził zespół pod kierunkiem M. Kolczyńskiego (2013). 


\begin{tabular}{|c|c|c|c|c|}
\hline 1 & 2 & 3 & 4 & 5 \\
\hline Belgia & $\begin{array}{l}\text { De Morgen } \\
\text { De Standaard } \\
\text { Het Laatste Nieuws } \\
\text { Het Niuewsblad } \\
\text { Knack } \\
\text { De Tijd } \\
\text { Het Belang van Limburg } \\
\text { Gazet van Atwerpen }\end{array}$ & $15.06 .2011-17.01 .2012$ & 735 & 1,6 \\
\hline Estonia & $\begin{array}{l}\text { delfi.ee } \\
\text { epl.ee } \\
\text { postimees.ee } \\
\text { err.ee }\end{array}$ & $15.06 .2011-15.01 .2012$ & 1099 & 3,5 \\
\hline \multirow[t]{3}{*}{ Grecja } & $\begin{array}{l}\text { Media online: } \\
\text { ert.gr } \\
\text { skai.gr } \\
\text { aixmi.gr } \\
\text { madata.gr } \\
\text { newsit.gr } \\
\text { newsbomb.gr } \\
\text { Wersje elektroniczne dzienników: } \\
\text { tovima.gr } \\
\text { avgi.gr } \\
\text { eleftherotypia.gr }\end{array}$ & $\begin{array}{l}15.06 .2011-30.01 .2012 \\
15.06 .2011-15.01 .2012 \\
15.06 .2011-15.01 .2012\end{array}$ & 122 & 46,7 \\
\hline & $\begin{array}{l}\text { Tygodniki: } \\
\text { Kiriakatiki Eleftherotipia } \\
\text { To Vima }\end{array}$ & $\begin{array}{l}15.06 .2011-18.12 .2011 \\
15.06 .2011-15.01 .2012\end{array}$ & 56 & 23,6 \\
\hline & $\begin{array}{l}\text { Telewizja: } \\
\text { SKAI Television } \\
\text { NET }\end{array}$ & $\begin{array}{l}15.06 .2011-15.01 .2012 \\
15.06 .2011-30.01 .2012\end{array}$ & 14 & 42,9 \\
\hline Niemcy & $\begin{array}{l}\text { Süddeutsche Zeitung } \\
\text { Frankfurter Allgemeine Zeitung } \\
\text { Bild } \\
\text { Der Spiegel }\end{array}$ & $\begin{array}{r}15.06 .-31.07 .2011 \\
1.09 .-15.10 .2011 \\
1.12 .2011-15.01 .2012\end{array}$ & 1353 & 5,5 \\
\hline Polska & $\begin{array}{l}\text { Gazeta Wyborcza } \\
\text { Rzeczpospolita } \\
\text { Fakt } \\
\text { Nasz Dziennik } \\
\text { Polityka } \\
\text { Wprost } \\
\text { Uważam rze }\end{array}$ & $\begin{array}{r}15.06 .-31.07 .2011 \\
1.09 .-15.10 .2011 \\
1.12 .2011-15.01 .2012\end{array}$ & \multicolumn{2}{|c|}{$767(100 \%)^{*}$} \\
\hline \multirow[t]{2}{*}{ Rumunia } & $\begin{array}{l}\text { Gazety: } \\
\text { Jurnalul National Adevarul } \\
\text { Romania Libera } \\
\text { Libertatea } \\
\text { Revista } 22 \\
\end{array}$ & \multirow[t]{2}{*}{$1.06 .2011-15.01 .2012$} & 1668 & 15,7 \\
\hline & $\begin{array}{l}\text { Media online: } \\
\text { Hotnews } \\
\text { Ziare.com } \\
\text { Euractiv }\end{array}$ & & 1047 & 36,2 \\
\hline Stacja 'Eur & & 30.03.2011-30.01.2012 & 71 & 22,0 \\
\hline
\end{tabular}

* Analizie zostały poddane wyłącznie materiały dotyczące bezpośrednio polskiej prezydencji.

Źródło: Projekt „Media Coverege of the Polish EU Presidency” (zob. też: Stępińska, 2012). 
Media koncentrowały się przede wszystkim na tematyce gospodarczej, spotkaniach o charakterze politycznym oraz wydarzeniach towarzyszących prezydencji, $\mathrm{w}$ tym imprezach kulturalnych (w Austrii 14\% materiałów dotyczyła kultury, w Belgii 12\%, a w Niemczech aż 19\%, podczas gdy w Grecji temat praktycznie nie był podejmowany). Warto zauważyć, że istotna część publikacji dotyczyła także tematyki sportowej, w tym przygotowań do EURO 2012. W Belgii tematyka sportowa stanowiła blisko $40 \%$ wszystkich materiałów poświęconych Polsce w badanym okresie, w Austrii i Niemczech blisko 30\%, zaś w Rumunii $21 \%$ w prasie drukowanej i $12 \%$ w mediach online. W tym samym czasie tematyka polityczna i stosunki międzynarodowe stanowiły w Austrii 17\%, w Rumunii 16\%, a w Niemczech 14\% materiałów. Wreszcie, część materiałów dotyczyła polityki krajowej Polski (w okresie prezydencji odbyły się wybory parlamentarne). Tematyce tej poświęcono 8\% materiałów w Niemczech i Grecji, 7\% w Austrii i Rumunii, 1,5\% w Belgii. Natomiast w Polsce aż jedna piąta artykułów bezpośrednio odnoszących się do prezydencji skoncentrowana była na tematyce polityki krajowej, podczas gdy jedna trzecia (35\%) na relacjach międzynarodowych, 17\% na kulturze, zaś $16 \%$ na gospodarce.

Wyniki prowadzą do wniosku, iż sam fakt przewodnictwa danego państwa w Radzie UE nie gwarantuje szczególnej uwagi mediów zagranicznych. Niemniej, analiza zawartości mediów zagranicznych pozwala na stwierdzenie, jaki obraz danego państwa rozpowszechniają dziennikarze wśród europejskich społeczeństw. Warte jest przy tym podkreślenia, że Polska w zdecydowanej większości materiałów prezentowana była jako „państwo członkowskie UE” (pryzmat unijny), znacznie rzadziej zaś jako „państwo postkomunistyczne” (pryzmat historyczny) czy „państwo Europy Środkowo-Wschodniej" (pryzmat geopolityczny). W przypadku takich państw jak Austria i Niemcy znacząca była także zmiana w sposobie portretowania Polski przed rozpoczęciem i po zakończeniu prezydencji (zob. Tabela 2 ) - z „,nowego państwa członkowskiego" na ,państwo członkowskie”.

Tabela 2

Sposób prezentowania Polski w prasie austriackiej i niemieckiej (\%)

\begin{tabular}{|c|c|c|c|}
\hline & $\begin{array}{l}\text { Okres przed } \\
\text { prezydencją }\end{array}$ & $\begin{array}{c}\text { Okres } \\
\text { prezydencji }\end{array}$ & $\begin{array}{c}\text { Okres po } \\
\text { prezydencji }\end{array}$ \\
\hline \multicolumn{4}{|c|}{ AUSTRIA } \\
\hline Państwo członkowskie & 87,5 & 88,6 & 100 \\
\hline Nowe państwo członkowskie & 12,5 & 2,3 & 0 \\
\hline Organizator spotkania & 0 & 4,5 & 0 \\
\hline Państwo Europy Środkowo-Wschodniej & 0 & 0 & 0 \\
\hline \multicolumn{4}{|c|}{ NIEMCY } \\
\hline Państwo członkowskie & 80 & 83,1 & 60 \\
\hline Nowe państwo członkowskie & 20 & 8,5 & 0 \\
\hline Organizator spotkania & 0 & 3,4 & 0 \\
\hline Państwo Europy Środkowo-Wschodniej & 0 & 3,4 & 0 \\
\hline Inne & 0 & 1,7 & 40 \\
\hline
\end{tabular}

Źródło: Wöhlert, 2013a, s. 102 ; Wöhlert, 2013b, s. 137. 
Analizowana była także ocena polskiej prezydencji i stosunek wobec Polski wyrażany przez dziennikarzy w mediach zagranicznych: spośród badanych państw najbardziej krytyczną postawę reprezentowały media belgijskie (25\% materiałów zawierało negatywną ocenę, ale tyle samo było tam materiałów o pozytywnej wymowie, zaś $42 \%$ zawierało zarówno pozytywne, jak i negatywne oceny). Najwięcej pozytywnych materiałów pojawiło się w greckich mediach online (blisko 39\%), w Austrii (28\%), Belgii ( $25 \%)$ oraz w rumuńskich mediach online (25\%). W Austrii, Estonii i Rumunii większość materiałów nie zawierała żadnych ocen (Stępińska, 2012, s. 79-80). Negatywny wydźwięk materiałów wynikał m.in. z orientacji politycznych analizowanych tytułów prasowych (np. w Belgii i Austrii) i przyjętej przez nie sceptycznej lub wręcz krytycznej postawy wobec UE. Z kolei w prasie niemieckiej i austriackiej głosy krytyki pojawiły się głównie w trakcie i pod koniec okresu polskiego przewodnictwa: wykazywano bezsilność państwa sprawującego tę funkcję w sytuacji kryzysu ekonomicznego. $\mathrm{Na}$ pierwszym planie były przez cały ten okres państwa o silnej pozycji gospodarczej i politycznej w UE i strefie euro: Niemcy, Wielka Brytania, Francja. W istocie nie była to zatem bezpośrednia krytyka Polski, a raczej odzwierciedlenie realnej pozycji i roli poszczególnych państw w ramach Unii Europejskiej.

\section{Podsumowanie}

Świadomość istnienia deficytu komunikacyjnego w procesie integracji europejskiej zaowocowała szeregiem inicjatyw podejmowanych przez instytucje unijne i państwowe. Wykorzystywane są w nich zarówno narzędzia komunikacji bezpośredniej, jak i media, w tym media społecznościowe. Niemniej, tradycyjne media, takie jak prasa i telewizja wciąż stanowią jedno z najważniejszych źródeł wiedzy o bieżących wydarzeniach krajowych i zagranicznych. Wyniki badań prowadzonych w ostatnich latach prowadzą do wniosku, że Unia Europejska nie tyle stanowi odrębny temat informacji zamieszczanych w mediach, co raczej kontekst wydarzeń, które media opisują (wyjątek stanowią kluczowe wydarzenia cykliczne, typu wybory do Parlamentu Europejskiego lub wydarzenia przełomowe, jak choćby wprowadzenie wspólnej waluty). Europeizacja sfery publicznej nie może być zatem mierzona jedynie liczbą materiałów, które ukazują się w mediach w danym okresie, ale także częstotliwością stosowania określonej ramy interpretacyjnej podczas prezentowania zarówno wydarzeń krajowych, jak i zagranicznych.

\section{Bibliografia}

Almaney A. (1970), International and Foreign Affairs on Network Television News, „Journal of Broadcasting", vol. 14, $\mathrm{nr} 4$.

Boomgaarden H. G., Vliegenthart R., de Vreese C. H., Schuck A. R. T. (2010), News on the Move: Exogenous Events and News Coverage of the European Union, „Journal of European Public Policy", vol. 17, $\mathrm{nr} 4$.

Chang T. K., Lee J. W. (1992), Factors affecting gatekeepers'selection of foreign news: A national survey of newspaper editors, „Journalism Quarterly”, vol. 69, $\mathrm{nr} 3$. 
Cianciara A. K. (2012), Rotating Presidency within the Post-Lisbon Insitutional Dynamics: Politically Irrelevant?, „Yearbook of Polish European Studies”, vol. 15.

De Swert K., De Smedt J. (2014), Hosting Europe, Covering Europe? Domestication in the EU-Coverage on Belgian Television News (2003-2012), w: Media and Communication in Europe, red. A. Stępińska, Logos Verlag, Berlin.

de Vreese C. H. (2001), Europe in the News: A cross-national comparative study of the news coverage of key EU events, „European Union Politics”, nr 2.

de Vreese C. H., Boomgaarden H. (2005), Projecting EU referendums: Fear of immigration and support for European integration, ,European Union Politics”, nr 1.

de Vreese C. H., Peter J., Semetko H. A. (2001), Framing politics at the launch of the euro: A cross-national comparative study of frames in the news, „Political Communication”, $\mathrm{nr} 2$.

de Vreese C. H., Semetko H. A. (2004), Political campaigning in referendums: Framing the referendum issue, Routledge, London.

Ekengren M. (2004), National Foreign Policy Co-ordination: the Swedish EU Presidency, w: Contemporary European Foreign Policy, red. W. Carlsnaes, H. Sjursen, B. White, Sage Publication.

Eriksen E. O., Fossum J. E. (red.) (2000), Democracy in the European Union: Integration through Deliberation?, Routledge, Abingdon.

Gerbner G., Marvanyi G. (1977), The many worlds of the world's press, „Journal of Communication”, vol. 27 , nr 1.

Galtung J., Ruge M. (1965), The structure of foreign news: The presentation of the Congo, Cuba and Cyprus crises in four Norwegian newspapers, ,Journal of Peace Research”, nr 1.

Gripsrud J. (2007), Television and the European Public Sphere, „European Journal of Communication”, vol. $22, \mathrm{nr} 4$.

Habermas J. (1998), Between Facts and Norms: Contributions to a Discourse Theory of Law and Democracy, MIT Press, Cambridge.

Habermas J. (2000), The Inclusion of the Other: Studies in Political Theory, MIT Press, Cambridge.

Harcup T., O’Neill D. (2001), What is news? Galtung and Ruge Revisited, „Journalism Studies”, vol. 2 , nr 5 .

Hepp A. i inni (2012), Politische Diskurskulturen in Europa: die Mehrfachsegmentierung europäischer Öffentlichkeit, VS Verlag, Wiesbaden.

Husak T. (2012), The , Stability Role” of the Presidency of the Council of the EU in an Evolving Institutional Framework, „Yearbook of Polish European Studies”, vol. 15.

Kayser J. (1953), One week's news. Comparative study of 17 major dailies for a seven-day period, UNESCO, Paris.

Kolczyński M. (red.) (2013), Obraz prezydencji Polski w Radzie Unii Europejskiej (2011) w wybranych tytułach prasy polskiej, GNOME - Wydawnictwa Naukowe i Artystyczne, Katowice.

Koopmans R., Statham P. (red.) (2010), The making of a European public sphere: Media discourse and political contention, Cambridge University Press, Cambridge.

Koopmans R., Erbe J. (2004), Towards a European public sphere? Vertical and horizontal dimensions of Europeanized political communication, „Innovation: The European Journal of Social Science Research", vol. 17, nr 2.

Maier M., Strömbäck J., Kaid L. L. (2012), European Political Communication: Campaign Strategies, Media Coverage, and Campaign Effects in European Parliamentary Elections, Ashgate.

McCombs M. (2006), Setting the agenda. The mass media and public opinions, Polity Press.

Meyer C. (1999), Political Legitimacy and the Invisibility of Politics: Exploring the European Union's Communication Deficit, „Journal of Common Market Studies”, vol. 37, $\mathrm{nr} 4$. 
Mieńkowska-Norkiene R. (2012), The Limited Role of the Council Presidency After Lisbon - Much Ado About Nothing?, „Yearbook of Polish European Studies”, vol. 15.

Offerhaus A., Mollen A., Hepp A. (2014), Nationalizing Europe Regionally - The Europeanization of Public Spheres in Regional Newspaper Reporting and the ,Crisis” in Europe, w: Media and Communication in Europe, red. A. Stępińska, Logos Verlag, Berlin.

Perez F. (2013), Political Communication in Europe. The Cultural and Structural Limits of the European Public Sphere, Palgrave Macmillan.

Peters B. (2008), Public Deliberation and Public Culture, Palgrave Macmillan, Basingstoke.

Quaglia L., Moxon-Brown M. (2006), What makes a good EU presidency? Italy and Ireland compared, „Journal of Common Market Studies”, vol. 44, nr 2.

Schlesinger P. (1999), Changing Spaces of Political Communication: The Case of the European Union, „Political Communication”, vol. 16, nr 3.

Schlesinger P., Kevin D. (2000), Can the European Union Become a Sphere of Publics?, w: Democracy in the European Union: Integration through Deliberation?, red. E. O. Eriksen, J. E. Fossum, Routledge, Abingdon.

Sreberny-Mohammadi A., Nordenstreng K., Stevenson R., Ugboajah F. (1985), Foreign news in the media: International reporting in 29 countries, UNESCO, Paris.

Sreberny A., Stevenson R. (1999), Comparative Analysis of International News Flow: An Example of Global Media Monitoring, w: International media monitoring, red. K. Nordenstreng, M. Griffin, Hampton Press, Cresskill NJ.

Stępińska A. (2012), Media Coverage of the Polish EU Presidency, „Yearbook of Polish European Studies", nr 15.

Stępińska A. (2013), International project: Media Coverage of the EU Presidency, „Środkowoeuropejskie Studia Polityczne", nr 3.

Trenz H.-J. (2004), Media Coverage on European Governance: Exploring the European Public Sphere in National Quality Newspapers, „European Journal of Communication”, vol. 19, nr 3.

van Dalen A. (2014), The Changing EU Presidency and the Media Agenda at Home: Coverage of the Danish 2002 and 2012 Presidency Compared, w: Media and Communication in Europe, red. A. Stępińska, Logos Verlag, Berlin.

Veltri G. A. (2012), Information flows and centrality among elite European newspapers, „European Journal of Communication", vol. 27, nr 4.

Wanta W., Mikusova S. (2010), The agenda-setting process in international news, „Central European Journal of Communication", nr 5.

Wessler H. i inni (2008), Transnationalization of Public Spheres, Palgrave Macmillan, Basingstoke.

Wilke J., Heimprecht C. (2011), Europe in Europe and Europe in the world, w: News in Europe, Europe on news, red. A. Stępińska, Logos Verlag, Berlin.

Wilke J., Reinemann C. (2007), Invisible second-order campaigns? A longitudinal study of the coverage of the European Parliamentary elections 1979-2004 in four German quality newspapers, "Communications", nr 32.

Wilke J. (1987), Foreign news coverage and international news flow over three centuries, „Gazette”, vol. 39 , nr 3.

Wilke J., Heimprecht C., Ito Y. (2013), Countries of Location and Countries Involved, w: Foreign News on Television. Where in the World Is the Global Village?, red. A. A. Cohen i inni, Peter Lang.

Woodward J. L. (1930), Foreign news in American morning newspapers. A study in public opinion, New York. 
Wöhlert R. (2013a), Austrian News Coverage of Poland during the Polish EU Presidency Term in 2011, „Środkowoeuropejskie Studia Polityczne”, nr 3.

Wöhlert R. (2013b), German News Coverage of Poland during the Polish EU Presidency Term in 2011, „Środkowoeuropejskie Studia Polityczne”, nr 3.

Wu H. D. (2000), Systemic determinants of international news coverage: A comparison of 38 countries, ,Journal of Communication”, nr 2.

Wu H. D (1998), Investigating the determinants of international news flow. A meta-analysis, „Gazette", nr 6 .

\section{Streszczenie}

Świadomość istnienia deficytu komunikacyjnego w procesie integracji europejskiej zaowocowała szeregiem inicjatyw podejmowanych przez instytucje unijne i państwowe. Wykorzystywane są w nich zarówno narzędzia komunikacji bezpośredniej, jak i media, w tym media społecznościowe. Niemniej, tradycyjne media, takie jak prasa i telewizja wciąż stanowią jedno z najważniejszych źródeł wiedzy o bieżących wydarzeniach krajowych i zagranicznych. W praktyce bowiem wymiar wertykalny europeizacji sfery publicznej przejawia się w częstym prezentowaniu w materiałach dziennikarskich (i szerzej, debacie publicznej) instytucji Unii Europejskiej lub kierunków polityki UE w różnych obszarach. Z kolei wymiar horyzontalny wyraża się w międzynarodowej wymianie informacji, argumentów i poglądów, w tym w prezentowaniu $\mathrm{w}$ mediach $\mathrm{w}$ różnych państwach wypowiedzi przedstawicieli innych państw oraz opisywaniu wydarzeń mających miejsce w innych państwach europejskich.

Słowa kluczowe: Unia Europejska, media, informacja, sfera publiczna, europeizacja

\section{How much Europe in European news media? The role of the media in shaping the European public sphere}

\section{Summary}

The awareness of the communications deficit in the process of European integration has stimulated a number of initiatives undertaken by EU and state institutions. They use both the tools of direct communication and the media, including social media. Yet the traditional media, such as the printed press and TV, continue to be among the most important sources of information about current domestic and foreign events. In practice, the vertical dimension of the Europeanisation of the public realm is manifested in the form of journalistic coverage (and, more broadly, in public debate) of EU institutions and EU policies in different areas. The horizontal dimension is expressed by means of the international exchange of information, arguments and opinions, including the presentation of representatives of different countries in the media and covering events taking place in other European countries.

Key words: European Union, the media, information, public sphere, Europeanisation 